\title{
Microstructure and Mechanical Properties for TIG Welding Joint of High Boron Fe-Ti-B Alloy
}

\author{
He Lin ${ }^{1}, \quad$ Liu Ying ${ }^{1.2}, \quad$ Li Jun ${ }^{1.2}, \quad$ Li Binghong ${ }^{1}$ \\ ${ }^{1}$ Sichuan University, Chengdu 610065, China; ${ }^{2}$ Key Laboratory of Advanced Special Material \& Technology, Ministry of Education, \\ Chengdu 610065, China
}

\begin{abstract}
The hot rolled plates of high boron Fe-Ti-B alloys were butt-welded by gas tungsten arc welding (TIG) using base metal as the filler. The microstructures of the TIG weld joints were analyzed. The results indicate that the welding quality of the high boron Fe-Ti-B alloys is very good, there are no obvious defects such as cracks, lack of fusion, incomplete penetration and strip defects in the butt weld joints. The microstructures of the weld metal and the heat affected zone are different from that of the base metal significantly. However, the micro-zone composition analysis indicates that the composition of the TIG weld joint is very uniform. Tensile tests were carried out on TIG welded joints after the post weld heat-treatment. The result shows that the welds have slightly higher yield strength (YS), and lower ultimate tensile strength compared to those of the base metal. However, the tensile properties reach a high level. The tensile strength of the high boron Fe-Ti-B alloys is higher than $580 \mathrm{MPa}$, and the yield strength is higher than $400 \mathrm{MPa}$.
\end{abstract}

Key words: high boron Fe-Ti-B alloy; TIG; microstructure; mechanical property

Boron has received more and more attentions due to its great potential applications, such as improving of the hardenability of materials, enhancing of the thermal stability and the neutron shielding properties ${ }^{[1-5]}$. However, the solubility of boron is very low in iron ${ }^{[2,6]}$. Adding of an excessive boron results in the formation of continuous eutectic boride $\mathrm{M}_{2} \mathrm{~B}$ ( $\mathrm{M}$ represents $\mathrm{Fe}, \mathrm{Cr}$ or $\mathrm{Mn}$ ) network along the grain boundaries. Thereby, high boron Fe-B alloys are embrittle and the mechanical properties are deteriorated $^{[7,8]}$. Titanium is a stronger boride former, which can form stable boride $\mathrm{TiB}_{2}$ with boron. Moreover, $\mathrm{TiB}_{2}$ is relatively stable in liquid $\mathrm{Fe}$. The forming of $\mathrm{TiB}_{2}$ can take away available boron before the solidification of $\alpha$-Fe phase, which can reduce or eliminate the continuous $\mathrm{Fe}_{2} \mathrm{~B}$ network. The mechanical properties are also improved with the adding of titanium. Some investigations [9-11] have successfully alloyed a small amount of titanium to overcome the boride embrittlement and prevent the formation of $\mathrm{M}_{2} \mathrm{~B}$ network.

Ordinary high-boron steels have a poor weldability, which even can't be welded, owing to the presence of the continuous $\mathrm{Fe}_{2} \mathrm{~B}$ network which exists along the grain boundaries. However, it can eliminate the continuous $\mathrm{Fe}_{2} \mathrm{~B}$ networks by adding titanium. Whether this high boron steel can be welded, it need to test and systematically research. Gas tungsten arc welding (TIG) is a widely used welding method for its high quality welds and relatively lower equipment investment ${ }^{[12-15]}$. In this process, a tungsten electrode is shielded by a flow of inert and/or reducing gases such as argon (normally employed), helium, nitrogen, hydrogen or blends. In TIG process, an electric arc is formed between an inconsumable tungsten electrode and the work piece ${ }^{[16]}$. The arc provides the thermal energy to melt the work pieces as well as the filler if necessary. TIG has a numerous advantages, such as (a) weld metal has high purity because of the inert gas protection, (b) the deformation of weld is small due to the heating is concentrated when welding, and (c) the electric arc is stable which can stably combust even in a small current $(<10 \mathrm{~A})$. Furthermore, TIG is easy to accomplish the mechanization and automation. In this study, the hot rolled plates of the high boron Fe-Ti-B alloys were butt-welded by TIG under

Received date: March 25, 2013

Foundation item: the Financial Supports Provided by the Fundamental Research Funds for the Central Universities (NCET-04873)

Corresponding author: Liu Ying, Ph. D., Professor, School of Materials Science and Engineering, Sichuan University, Chengdu 610065, P. R. China, Tel: 0086-28 85405536, E-mail: Liuying5536@163.com 
identical conditions using base metal as the filler. Tensile tests were carried out on TIG welded joints after post weld heat-treatment. With metallurgical and the microstructures observations, microstructure in the TIG weld joints were analyzed. The objective of this study is to characterize and analyze the microstructures and mechanical properties of TIG welds. It is expected that the preliminary results can be significant in the application of high boron Fe-Ti-B alloys.

\section{Experiment}

In the present work, the hot-rolled plates of the high boron Fe-B alloys with $6 \mathrm{~mm}$ thickness were used, and the contents of boron were $1.0 \mathrm{wt} \%, 1.8 \mathrm{wt} \%$ and $2.1 \mathrm{wt} \%$, respectively. The contents of titanium were $2.215 \mathrm{wt} \%$, $3.988 \mathrm{wt} \%$ and $4.652 \mathrm{wt} \%$, respectively, which corresponded to $\mathrm{TiB}_{2}$ stoichiometric ratio $(1: 2)$. Fe was for the balance. Plates with $60^{\circ} \mathrm{X}$-groove were TIG welded under identical conditions using base metal as the filler. Welding current was $100 \mathrm{~A}$, welding voltage was $15 \mathrm{~V}$, the protecting gas was argon, the flows was about $10 \mathrm{~L} / \mathrm{min}$, the back of weld was also protected by argon, welding speed was about 2 $\mathrm{mm} / \mathrm{s}$. Annealing process was performed in order to relieve the internal stresses of the welds. The temperature of the post weld heat-treatment (PWHT) was $873 \mathrm{~K}$, and the holding time was $2 \mathrm{~h}$.

$\mathrm{X}$-ray phase analysis of the specimens was performed with DX-2000 diffractometer using $\mathrm{Cu} \mathrm{K} \alpha$ radiation operating at $30 \mathrm{kV}$ and $40 \mathrm{~mA}$. Metallographic specimens were prepared in accordance with standard procedures, and all joint samples were etched with a $4 \%$ nital solution. Microstructure observation was carried out by optical microscopy (OM) and JSM-6490LV scanning electron microscope (SEM). The micro-zone composition analysis was investigated using GENESIS 2000 XMS energy dispersive X-ray spectrometry (EDS) system which was attached to the SEM. Dog bone shaped sheet specimens were used for tensile testing. The gauge length, width and thickness of the specimens were $50,12.5$ and $5 \mathrm{~mm}$, respectively. The tensile specimens were cut from the welded plates by an electrical discharge machining. According to ASTM E8-04, tensile tests were performed on Shimadzu AG-10TA materials testing system. Experiment results were average values of three specimens.

\section{Results and Discussion}

\subsection{Microstructure observation}

The macroscopic overview and the optical metallographic examinations of the cross-section of TIG weld joints after PWHT are shown in Fig.1 and Fig.2, respectively. Results show that the welding quality is very good, there are no obvious defects such as cracks, lack of fusion, incomplete penetration and strip defects in the butt weld joints. The weld metal (WM), the heat affected zone (HAZ), the base metal (BM) can be identified clearly. The microstructure of $W M$ is different from the $B M$ significantly. The $\mathrm{TiB}_{2}$ particulates with $2 \sim 5 \mu \mathrm{m}$ are uniformly distributed in the matrix of BM. For WM, a part of $\mathrm{TiB}_{2}$ particles are dispersed in the Fe matrix. The other part of $\mathrm{TiB}_{2}$ form $\mathrm{Fe}-\mathrm{TiB}_{2}$ eutectics with $\alpha$-Fe. The Fe-TiB

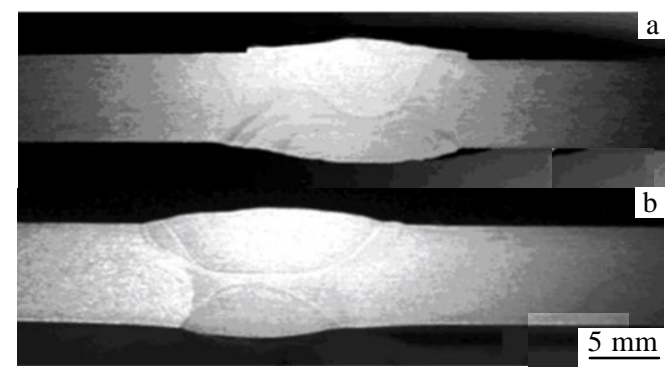

Fig.1 Cross-section of weld joints with different B contents: (a) $1.0 \mathrm{wt} \% \mathrm{~B}$ and (b) $1.8 \mathrm{wt} \% \mathrm{~B}$

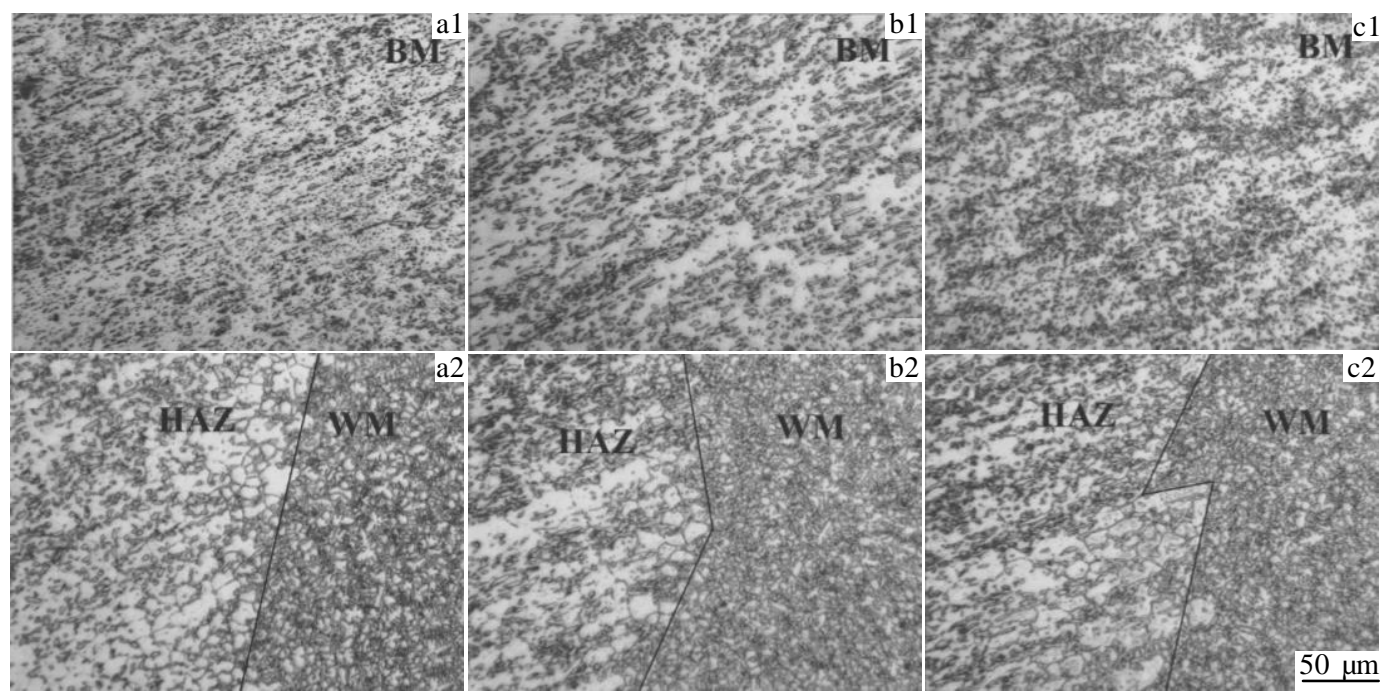

Fig.2 Optical metallograph of the TIG weld joints with different B content: (a) $1.0 \mathrm{wt} \%$, (b) $1.8 \mathrm{wt} \%$, and (c) $2.1 \mathrm{wt} \%$ 
eutectics are continuous network and distributed along grain boundaries. However, the distribution of $\mathrm{TiB}_{2}$ is uniform from the overall. Furthermore, we can see that the grain size of HAZ is bigger than that of BM.

The microstructures are closely associated with the TIG process. During TIG, the WM experiences secondary metallurgy. There are only two phases $(\alpha-\mathrm{Fe}$ and TiB2) in the alloy. During the solidification, some TiB2 will be first precipitated out since the $\mathrm{TiB}_{2}$ particle has a higher melting point $(3498 \mathrm{~K})$ than $\alpha$-Fe $(1808 \mathrm{~K})$, and acts as nucleus for the heterogeneous nucleation of $\alpha$-Fe. With the decrease of the temperature, $\alpha$-Fe will be quickly formed. The $\mathrm{TiB}_{2}$ in the residual alloy liquid will gather, grow up and form Fe- $\mathrm{TiB}_{2}$ eutectics with $\alpha$-Fe. It leads to a microstructure with continuous $\mathrm{Fe}-\mathrm{TiB}_{2}$ eutectics network. On the contrary, the $\mathrm{BM}$ has been hot rolled before. The alloy recrystallizes in the hot rolling process, and the $\mathrm{Fe}-\mathrm{TiB}_{2}$ eutectics are broken into particles. In conclusion, the microstructure of WM is significantly different from that of the BM. The HAZ and argon can transfer a large amount of heat from the liquid alloy, and the solidification rate of the liquid alloy in the molten poor is faster. Thereby, the WM grains are fine. The HAZ experienced a complex thermal cycle, which results in the grains becoming coarse.

Fig.3 shows the X-ray diffraction patterns of BM and WM of the alloy with $1.0 \mathrm{wt} \%$ of B. It can be seen that the $\mathrm{BM}$ and WM have the same phase composition. Fig. 4 shows the EDS spectra of the TIG weld joint. The distributions of $\mathrm{Ti}, \mathrm{B}$ and $\mathrm{Fe}$ in $\mathrm{WM}, \mathrm{HAZ}$ and $\mathrm{BM}$ are homogeneous, as shown in Fig.4b, 4c and 4d. It indicates that the composition of the TIG weld joint is very uniform. This is a prerequisite to obtain good welding performance.

\subsection{Tensile properties}

Tensile properties of the welds and base metals are listed in Table 1. The welds have lower ultimate tensile strength (UTS) and elongation $\left(E_{\mathrm{r}}\right)$ than base metal. However, the yield strength (YS) is slightly higher. The above mentioned variations in the microstructures should affect the tensile properties accordingly. The $\mathrm{Fe}_{-} \mathrm{TiB}_{2}$ eutectics are distributed in the grain boundaries of $\alpha-\mathrm{Fe}$ as continuous network in the joints, which will deteriorate the mechanical properties seriously. The alloys will crack along the brittle phase (Fe- $\mathrm{TiB}_{2}$ eutectics) after small deformation. Thereby, the mechanical properties of the welds are poor, especially the elongation. For the $\mathrm{BM}, \mathrm{TiB}_{2}$ are distributed in the matrix as particles. Hard and brittle $\mathrm{TiB}_{2}$ particles distributed in the matrix uniformly can improve the strength significantly, which is due to the interaction between the particles and the dislocations. In addition, the grain size also has effects on the tensile properties. The grain size of the welds is larger than that of BM, which also results in the deterioration of tensile strength and elongation. Thereby, the tensile strength of the welds is lower than that of base metals. However, the welds have slightly higher yield

Table 1 Tensile properties of base metals and weld joints

\begin{tabular}{|c|c|c|c|c|c|c|c|}
\hline \multirow{2}{*}{$\begin{array}{c}\text { B content/ } \\
\text { wt } \%\end{array}$} & \multicolumn{3}{|c|}{ Base metals } & \multicolumn{3}{|c|}{ Weld joints } & \multirow{2}{*}{ Fracture position } \\
\hline & YS/MPa & UTS/MPa & $E_{\mathrm{r}} / \%$ & $\mathrm{YS} / \mathrm{MPa}$ & UTS/MPa & $E_{\mathrm{r}} / \%$ & \\
\hline 1.0 & 398 & 737 & 11.5 & 415 & 585 & 2.8 & WM \\
\hline 1.8 & 381 & 719 & 11.2 & 402 & 590 & 2.4 & WM \\
\hline 2.1 & 390 & 735 & 14.0 & 425 & 586 & 4.5 & WM \\
\hline
\end{tabular}

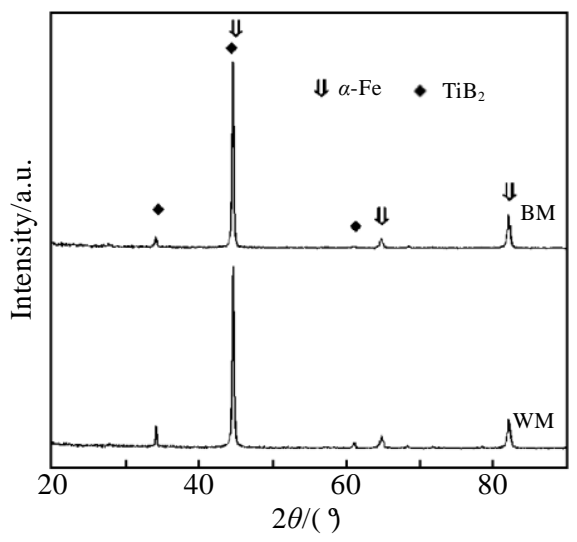

Fig.3 XRD patterns of BM and WM of the alloy with $1.0 \mathrm{wt} \%$ of $\mathrm{B}$

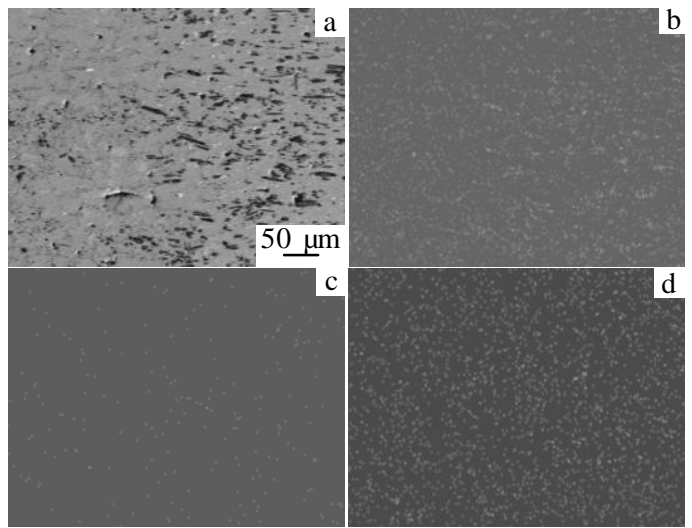

Fig.4 SEM-EDS analysis of the TIG weld joint of alloy with 1.0 wt\% B: (a) BSE image, (b) distribution of Ti, (c) distribution of $\mathrm{B}$, and $(\mathrm{d})$ distribution of $\mathrm{Fe}$ 
strength than base metal. The reason might be that (1) the grain sizes of $\mathrm{TiB}_{2}$ and base metals are increased; (2) the reinforcements in grain boundaries are increased; (3) the internal stress generated when welding is not completely eliminated after annealing process.

It is also worth noting that the tensile strength and yield strength reach a high level. The tensile strength of the high boron Fe-Ti-B alloys is higher than $580 \mathrm{MPa}$, and the yield strength is higher than $400 \mathrm{MPa}$, which even better than that of the general high boron steel in practical application. It is significant for the application of the high boron Fe-Ti-B alloys.

\section{Conclusions}

1) The hot rolled plates of high boron Fe-Ti-B alloys can be butt-welded by TIG. The welding quality is very good, and there are no obvious defects in the butt weld joints.

2) The WM, HAZ and BM can be identified clearly, and the microstructures of $\mathrm{WM}$ are different from BM significantly. The composition of the TIG weld joint is very uniform.

3) The welds have lower ultimate tensile strength and elongation than base metal, but have slightly higher yield strength. The tensile strength and yield strength reach a high level. The tensile strength of the welds is higher than $580 \mathrm{MPa}$, and the yield strength is higher than $400 \mathrm{MPa}$.

\section{References}

1 Li Y X, Liu Z L, Chen X. International Journal of Cast Metals Research[J], 2008, 21: 67
2 Jiménez J A, González-Doncel G, Ruano O A. Advanced Materials[J], 1995, 7: 130

3 Bastürk M, Kardjilov N, Lehmann E et al. IEEE Transactions on Nuclear Science [J], 2005, 52: 394

4 Guo H, Chaturvedi M C, Richards N L. Science and Technology of Welding and Joining[J], 1999, 4: 257

5 Xu S Q, Bourham M, Rabiei A. Materials and Design[J], 2010, 31: 2140

6 Sercombe T B. Materials Science and Engineering A[J], 2003, 363: 242

7 Guo C Q, Kelly P M. Journal of Materials Science [J], 2004, 39: 1109

8 Darabara M, Papadimitriou G D, Bourithis L. Surface and Coatings Technology[J], 2006, 201: 3518

9 Du B S, Zou Z D, Wang X H et al. Materials Letters[J], 2008, 62: 689

$10 \mathrm{Li} \mathrm{B} \mathrm{H,} \mathrm{Liu} \mathrm{Y,} \mathrm{He} \mathrm{L} \mathrm{et} \mathrm{al.} \mathrm{International} \mathrm{Journal} \mathrm{of} \mathrm{Cast}$ Metals Research[J], 2010, 23: 211

11 Liu Y, Li B H, Li J et al. Materials Letters[J], 2010, 64: 1299

12 Dong W C, Lu S P, Li D Z et al. International Journal of Heat and Mass Transfer[J], 2011, 54: 1420

13 Zhu Q, Lei Y C, Chen X Z et al. Fusion Engineering and Design[J], 2011, 86: 407

14 Song J L, Lin S B, Yang C L et al. Science and Technology of Welding and Joining [J], 2010, 15: 213

15 Balasubramanian M, Jayabalan V, Balasubramanian V. Journal of Materials Processing[J], 2008, 196: 222

16 Cabello Muňoz A, Rückert G, Huneau B et al. Journal of Materials Processing[J], 2008, 197: 337

\title{
高嗍 Fe-Ti-B 合金焊件微观结构和力学性能
}

何 林 $^{1}$, 刘 颖 ${ }^{1.2}$, 李 军 ${ }^{1.2}$, 李兵红 ${ }^{1}$

(1. 四川大学, 四川成都 610065)

(2. 先进特种材料及制备加工技术教育部重点实验室, 四川 成都 610065)

\begin{abstract}
摘 要: 采用铇极气体保护焊，以基体金属作为焊接填料，可以成功实现对高硼Fe-Ti-B合金的焊接。对焊件的微观结构进行了分 析, 研究表明, 高嗍Fe-Ti-B合金的焊接质量良好, 焊接接头处不存在裂纹、未熔合、未焊透等缺陷; 熔合区和热影响区的微观结 构与基体明显不同，但能谱分析表明其化学成分非常均匀。对焊件进行了力学性能测试。测试结果表明，相对于基体材料，焊件 的屈服强度略有升高, 但抗拉强度降低。尽管如此, 焊后高硼Fe-Ti-B合金的抗拉强度高于 $580 \mathrm{MPa}$, 屈服强度高于 $400 \mathrm{MPa}$, 焊件 的力学性能已达到一个较高的水平。
\end{abstract} 关键词：高嗍Fe-Ti-B合金；铇极气体保护焊；微观结构；力学性能

作者简介：何 林, 男, 1985 年生, 博士, 四川大学材料科学与工程学院, 四川成都 610065, 电话: 028-85405332, E-mail: zhibuyan@foxmail.com 